\title{
Endotoxemia analysis in the postoperative period following cardiac surgery
}

\author{
A Campos Gómez ${ }^{1 *}$, TM Tomasa Irriguible ${ }^{1}$, ML Cámara Rosell², E Jordana Lluch³ ${ }^{3}$ J Roca Antonio ${ }^{4}$, \\ $S$ Just Martinez ${ }^{1}, M$ Giménez Pérez ${ }^{3}$ \\ From ESICM LIVES 2015 \\ Berlin, Germany. 3-7 October 2015
}

\section{Introduction}

Endotoxin is a lipopolysaccharide in the membrane of gram negative bacilli, and is known to be one of the most potent activators of the inflammatory response in humans. In patients subjected to cardiac surgery, transient endotoxemia has been shown in many occasions, which seems to be closely related to extracorporeal circulation. The magnitude of endotoxemia, the high risk criteria and correlation with clinical evolution vary widely between studies.

\section{Objectives}

To examine the prevalence of endotoxemia related to cardiopulmonary bypass (CPB) in a cohort of patients undergoing cardiac surgery, using the Endotoxin Activity Assay (EAA). High risk criteria of endotoxemia were also investigated.

\section{Methods}

EAA assay was performed within two hours of ICU admission in a prospective observational study. An EAA of $<0.40$ units was judged as "low", and $\geq 0.40$ units as "high". Data collected included patient's demographics, cardiac history, EuroSCORE and intra-operative data collected included bypass time and the aortic cross clamp time, drugs and transfusions.

\section{Results}

A total of 107 patients were enrolled. The median age was 66 years (36-87), most were males (69\%), 38\% had diabetes, $71 \%$ hypertension, $12 \%$ peripheral vascular disease, $11 \%$ chronic renal failure and $21 \%$ were active smokers. Median EuroSCORE I was 6 (0-16). Out of

${ }^{1}$ Hospital Universitario Germans Trías i Pujol, Critical Care, Badalona, Spain Full list of author information is available at the end of the article
107, 99 were elective, 5 urgent and 3 emergent cardiac surgeries. 73 were valve replacement, 38 coronary vascular diseases, 12 aortic disease and 21 combined surgery. The median CPB time was 95 (24-300) and cross clamp time 68 (17-175) minutes. 37\% required blood transfusion. $88 \%$ required norepinephrine, $49 \%$ dobutamine and $17 \%$ epinephrine. Only 24 patients had EAA $\geq 0.4$ EA. We found a significant relation between peripheral vascular disease (OR 5,28(1,57-18,42), $\mathrm{p}=0,0070)$ and more red blood packs transfusion with higher EAA levels (OR 1,57 (1,06-3,06), $\mathrm{p}=0,06)$. On the other hand the rest of variables (demographics, cardiac history, EuroSCORE and intra-operative variables) were similar in both groups.

\section{Conclusions}

The results of the study indicate that in postoperative cardiac surgery there is endotoxemia at least in moderate degree. As risk factors, we found that patients with peripheral vascular disease and those who had been transfused with more red blood packs during surgery were at increased risk of endotoxemia.

\footnotetext{
Authors' details

${ }^{1}$ Hospital Universitario Germans Trías i Pujol, Critical Care, Badalona, Spain. ${ }^{2}$ Hospital Universitario Germans Trías i Pujol, Cardiac Surgery, Badalona, Spain. ${ }^{3}$ Hospital Universitario Germans Trías i Pujol, Microbiology, Badalona, Spain. ${ }^{4}$ Hospital Universitario Germans Trías i Pujol, Epidemiology, Badalona, Spain.
}

Published: 1 October 2015

\section{References}

1. Marshall JC, Foster D, Vincent JL, Cook DJ, Cohen J, Dellinger RP, Opal S, Abraham E, Brett SJ, Smith T, Mehta S, Derzko A, Romaschin A: Diagnostic and prognostic implications of endotoxemia in critical illness: results of the MEDIC study. J Infect Dis, United States 2004, 190:527-34.

2. Klein DJ, Briet F, Nisenbaum R, Romaschin AD, Mazer CD: Endotoxemia related to cardiopulmonary bypass is associated with increased risk of

\section{SpringerOpen ${ }^{\odot}$}

(C) 2015 Campos Gómez et al.; This is an Open Access article distributed under the terms of the Creative Commons Attribution License (http://creativecommons.org/licenses/by/4.0), which permits unrestricted use, distribution, and reproduction in any medium, provided the original work is properly cited. 
infection after cardiac surgery: a prospective observational study. Crit Care, England 2011, 15:R69.

doi:10.1186/2197-425X-3-S1-A106

Cite this article as: Campos Gómez et al.: Endotoxemia analysis in the

postoperative period following cardiac surgery. Intensive Care Medicine Experimental 2015 3(Suppl 1):A106.

\section{Submit your manuscript to a SpringerOpen ${ }^{\mathcal{O}}$ journal and benefit from:}

- Convenient online submission

- Rigorous peer review

- Immediate publication on acceptance

- Open access: articles freely available online

- High visibility within the field

- Retaining the copyright to your article

Submit your next manuscript at $\gg$ springeropen.com 